\title{
ANATOMICAL AND PHYSICAL CHARACTERISTICS OF Cephalostachyum mannii (Gamble) Stapleton - AN ENDEMIC SCRAMBLING BAMBOO OF NORTHEAST INDIA
}

\author{
Chaman Lal Sharma*, Madhubala Sharma, Dahunirikitre M. Lamare, Mahesh Wangkhem, \\ and Govinda Pangging \\ North Eastern Regional Institute of Science and Technology (NERIST) \\ Nirjuli (Itanagar), 791109 Arunachal Pradesh, India
}

Received: 17 August 2020, Revised: 20 April 2021, Accepted: 26 April 2021

\begin{abstract}
ANATOMICAL AND PHYSICAL CHARACTERISTICS OF Cephalostachyum mannii (Gamble) StapletonAN ENDEMIC SCRAMBLING BAMBOO OF NORTHEAST INDIA. Cephalostachyum mannii is a tall, graceful scandent bamboo with solid culms. It is distributed in Arunachal Pradesh, Meghalaya, Mizoram, and Nagaland states of Northeast India. The present study was carried out to investigate radial and vertical variations in anatomical and physical properties in the culms of this bamboo species. The mature culms (3-4 years old) were selected from forests of Amkassar Amlarem village, West Jaintia Hills District, Meghalaya, India. The selected internodes of culms were radially divided into outer, middle and inner zones, and vertically bottom, middle and top positions. The vascular bundles were of Type II and well developed in middle zones of both bottom and middle positions. The number and size of vascular bundles increased from inner to outer zone and decreased from bottom to top. Vessel length and vessel diameter decreased both radially and vertically. Among fibre characteristics, fibre wall thickness increased, while fibre length, fibre diameter, and fibre lumen diameter decreased significantly in both radial and vertical directions. Among physical properties, density increased, and moisture content decreased in both radial and vertical directions. Radial shrinkage was higher than tangential shrinkage. Both radial and tangential shrinkage decreased significantly from bottom to top. The fibres were long, thick-walled and highly rigid, and the derived indices do not satisfy the requirement as a superior fibrous raw material for pulp and paper making. However, this bamboo species has the potential for making good quality handicrafts and basketry.
\end{abstract}

Keywords: Solid culm, fibre, density, moisture content, shrinkage, vascular bundles

KARAKTERISTIK ANATOMIS DAN FISIK Cephalostachyum mannii (Gamble) Stapleton-SEBUAH BAMBU PENGERIKAN ENDEMIK DARI INDIA TIMUR. Cephalostachyum mannii adalab jenis bambu tinggi, skanden lentur dengan batang yang kokoh. Jenis ini tersebar di negara bagian Arunachal Pradesh, Meghalaya, Mizoram, dan Nagaland di India Timur Laut. Penelitian ini dilakukan untuk mengetabui variasi radial dan vertikal dalam sifat anatomis dan fisik batang spesies bambu ini. Batang dewasa berumur 3-4 tabun dipilib dari butan Desa Amkassar Amlarem, Distrik Perbukitan Jaintia Barat, Meghalaya, India. Ruas batang yang dipilih dibagi secara radial menjadi zona luar, tengah dan dalam, dan posisi bawah, tengah dan atas secara vertikal. Hasil penelitian menunjukkan bahwa batang bambu diketabui padat. Bundel vaskular tipe II dan berkembang dengan baik di zona tengah dari posisi bawah dan tengah. Jumlah dan ukuran ikatan pembuluh meningkat dari zona dalam ke zona luar dan menurun dari bawah ke atas. Panjang kapal dan diameter kapal menurun baik. secara radial maupun vertikal. Di antara karakteristik. serat, ketebalan dinding serat meningkat, sedangkan panjang serat, diameter serat, dan diameter lumen serat menurun secara signifikan baik, pada arah radial manpun vertikal. Berat jenis meningkat, dan kadar air menurun baik secara radial manpun vertikal. Penyusutan radial lebih tinggi dari susut tangensial, dan penyusutan radial dan tangensial menurun secara nyata dari bawah ke atas. Seratnya panjang, berdinding tebal dan sangat kaku, dan indeks turunannya tidak memenubi persyaratan sebagai bahan baku serat yang baik untuk pembuatan pulp dan kertas. Namun, jenis bambu ini berpotensi untuk dijadikan kerajinan tangan dan keranjang berkualitas baik.

Kata kunci: Batang padat, serat, kepadatan, kadar air, penyusutan, ikatan pembuluh

*Corresponding author: cls_chaman@yahoo.co.in 


\section{INTRODUCTION}

Bamboo is one of the most important nontimber forest resources of India. It is considered a versatile material due to fast growth, easy propagation, high strength to weight ratio, and a substitute for wood in composite wood industries and other value-added products (Tan, Rahbar, Allameh, Kwofie, Dissmore, Ghavami, \& Soboyejo, 2011). In India, they occur abundantly in deciduous and semievergreen forests of the North Eastern (NE) region and tropical moist deciduous forests of both North and South India. More than 50\% of bamboo resources have been reported from NE India and West Bengal. Bambusa cacharensis, Cephalostachyum mannii, Neomicrocalamus prainii, and Schizostachyum mannii are endemic species of North East India. Meghalaya, one of the eight North-Eastern states of India, is rich in bamboo resources. It is estimated to cover an area of 0.54 million ha and ranks $3^{\text {rd }}$ among northeastern states (FSI, 2019). There are 11 genera and 35 bamboo species in Meghalaya, out of which nine genera representing 32 species are sympodial type, and two genera with three species are monopodial type (Kharlyngdoh \& Barik, 2008). Dendrocalamus strictus, Dendrocalamus hamiltonii, Bambusa arundinacea, Bambusa pallida, and Bambusa tulda are the dominant clumpforming species, whereas Melocanna bambusoides constitute the non-clump forming species.

Anatomical, physical, and mechanical properties are important to determine the utilization of any bamboo species for various end uses. The strength, toughness, durability and preservative absorption of bamboos are related to anatomical properties (Razak, Mohamed, Samsi, Yunus, \& Moktar, (2006); Kelemwork, 2009) whereas, physical properties like density, moisture content and shrinkage (Razak, Mustafa, Sulaiman, Mohamed, Hassan, \& Khalid, 2010) govern the suitability of bamboos for different applications and their liability to chemical treatments. The fibre morphology and their derived indices, namely Runkel's ratio, slenderness ratio, flexibility and rigidity coefficients, are also essential to use bamboo fibrous raw material for pulp and paper making (Cao, Ma, Lin, Huang, Huang, \& Chen, 2014). Like wood, both anatomical and physical properties are highly variable in bamboos and vary with species, age and height positions (Grosser \& Liese, 1971; Sharma, Sharma, \& Laishram, 2017; Sharma, Sharma, Tado, \& Laishram, 2019).

Cephalostachyum mannii (Gamble) Stapleton syn. Neomicrocalamus mannii (Gamble) is a climbing bamboo species growing on hill slopes of tropical and subtropical zones of 700-1000 m.a.s.l. It is distributed in Arunachal Pradesh, Meghalaya, Mizoram, and Nagaland (Kharlyngdoh \& Barik, 2008). It is a tall, graceful bamboo species with solid culms and erect, narrow acicular culm sheath. The leaves have distinct central and secondary veins with a hair-point apex (Stapleton, Li, \& Xue, 1997). In NE India, only a few bamboo species are being used commercially due to a lack of basic information on the properties of other bamboo species. So far, there is no information related to the anatomical and physical properties of this wild bamboo species. Therefore, the present study attempts to obtain basic information on anatomical and physical properties and study the variations in these properties in both radial and vertical directions. The present study will assist in increasing the utilization of this species for different uses.

\section{MATERIAL AND METHOD}

\section{A. Study Site}

The culms of Cephalostachyum mannii (Gamble) Stapleton were collected from Amkassar Amlarem village, West Jaintia Hills District, Meghalaya. The geographical coordinates of the selected site were $25^{\circ} 17^{\prime} 12^{\prime \prime}$ N, 92 $06^{\circ} 20^{\prime \prime} \mathrm{E}$.

\section{B. Sample Collection}

Five mature culms (3-4 years old) of bamboo were collected randomly from different clumps. The bamboo culm was cut at about $30 \mathrm{~cm}$ 

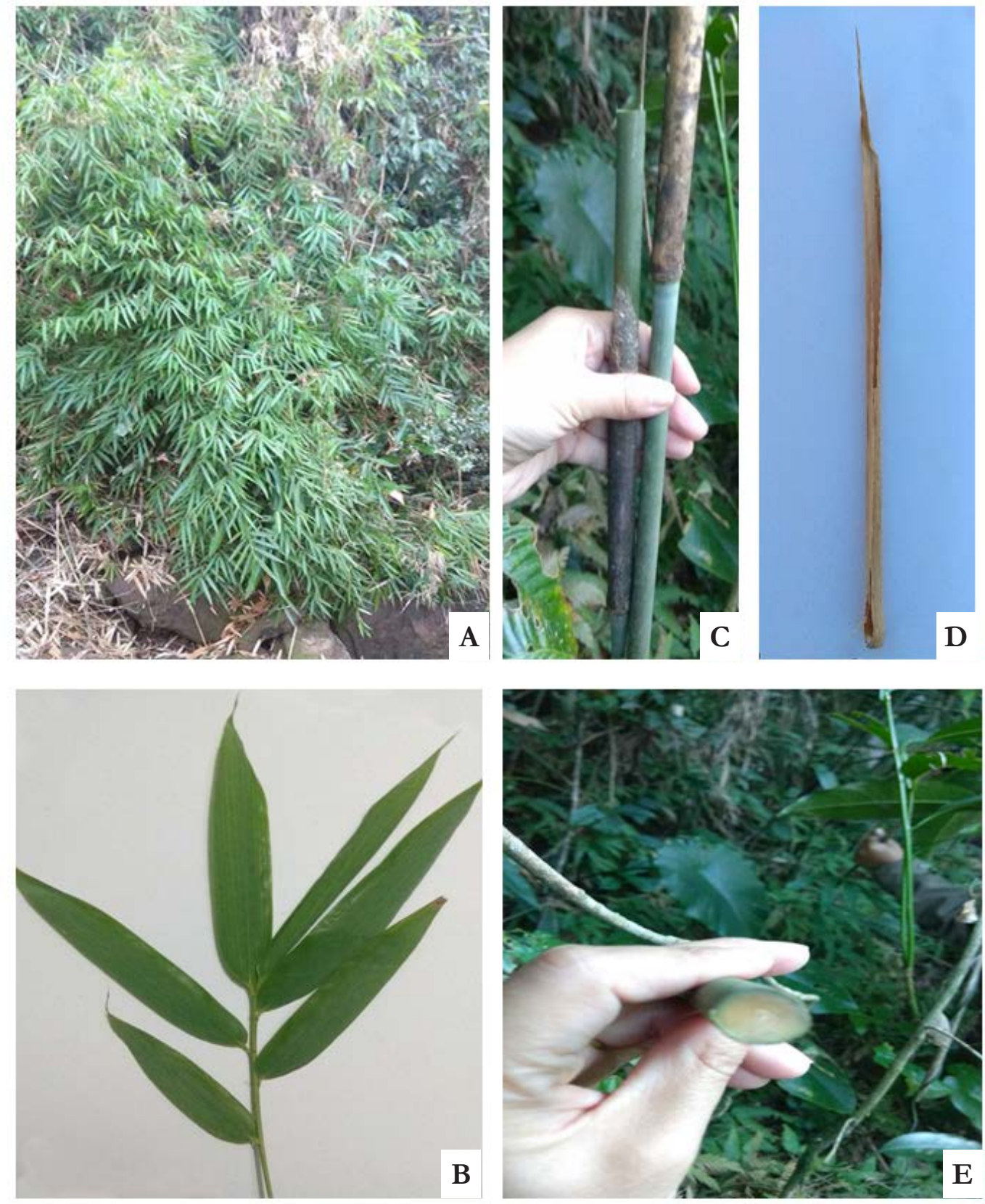

Figure 1. Morphology of Cephalostachyum mannii: clump (A), leaves (B), culms (C), culm sheath (D) and crosscut showing solid culm (E)

above ground level. Photographs of the whole clumps, leaves, and culm sheath were taken for identification. Then, the study measures the morphological parameters such as culm height, number of internodes, internode length, and internode diameters (Figure 1, Table 1). The unusable parts of the culms from the top were removed after harvesting. The culm age was estimated based on visual inspection by observing the colour, culm sheaths, and growth of surface lichens. Internodes were consecutively numbered from bottom to top for each culm and divided into three sections - bottom, middle, and top. The samples were taken from the middle portion of the internodes from bottom to top for further studies. The internodes were divided into inner, middle, and outer zones across the culm radially at each 
Table1: Morphological characteristics of Cephalostachyum mannii

\begin{tabular}{llr}
\hline Characteristics & & \multicolumn{1}{c}{$\begin{array}{c}\text { Range } \\
\text { (Mean } \pm \text { S.D) }\end{array}$} \\
\hline Culm height $(\mathrm{m})$ & & $4.11-5.67(4.73 \pm 0.60)$ \\
No. of internodes & Bottom & $9-11(9.4 \pm 0.89)$ \\
Internode length $(\mathrm{cm})$ & Middle & $38-72(55.44 \pm 11.07)$ \\
& Top & $19-66(50.31 \pm 13.78)$ \\
& Bottom & $30-64(45.67 \pm 8.66)$ \\
Internode diameter & Middle & $6.52-13.55(9.34 \pm 1.68)$ \\
$(\mathrm{mm})$ & Top & $5.73-11.68(8.57 \pm 1.65)$ \\
& & $5.18-12.64(8.26 \pm 1.79)$ \\
\hline
\end{tabular}

height positions. From each height positions, three internodes per culm were selected. A total of 45 internodes were selected for the present study.

\section{Preparation of Permanent Slides and Vascular Bundle Characteristics}

From the middle portion of the selected internodes, a sample of $2.5 \mathrm{~cm}$ length at each height position was cut and preserved in FAA solution for 24 hours and then shifted to $70 \%$ alcohol for further preservation. The cross-sections of 25-30 $\mu \mathrm{m}$ thickness of selected internodes were cut with the help of a sliding microtome, stained following standard procedure and permanent slides were prepared (Johansen, 1940). Radial and tangential diameters of vascular bundles in inner, middle, and outer zones at each height position (bottom, middle and top) were taken at $100 \mathrm{x}$ magnification. For these parameters, 30 vascular bundles per zone were selected. Stem samples from ten different fields from each zone (inner, middle, outer) were selected randomly from each height position to determine the number of vascular bundles per $\mathrm{mm}^{2}$. Types of vascular bundles present were classified according to Grosser and Liese (1971).

\section{Measurement of Cell Dimensions}

Thin bamboo splinters taken from each zone (inner, middle and outer) at each height position were treated with a mixture of glacial acetic acid and hydrogen peroxide in a ratio of $1: 1(\mathrm{v} / \mathrm{v})$ at $60^{\circ} \mathrm{C}$ for 24 hours till they became soft and white. The treated material was washed
2-3 times with water and gently shaken to obtain the fluffy white mass of fibres. 2-3 drops of safranin were added, and temporary slides were prepared in $50 \%$ glycerol to measure the fibres and vessels dimensions. A total of 50 fibres and 30 vessels from each zone at each height position were selected randomly. Fibre length and vessel length were taken at 40x magnification, while other dimensions like fibre diameter, fibre wall thickness, and vessel diameter were taken at 400x magnification. Derived indices like Runkel's ratio (Runkel, 1949), flexibility ratio (Wangaard, 1962), slenderness ratio (Varghese, Subramanian, Bennet, \& Jagadees, 1995), Luce's shape factor (Luce, 1970) and Rigidity co-efficient (Dutt, Upadhyaya, Tyagi, \& Malik, 2004) were determined to investigate the suitability of fibres for pulp and paper making.

\section{E. Determination of Physical Properties}

The moisture content and density of bamboo strips were determined by the methods given in IS 6874 (2008). A total of 135 strips were taken separately for the determination of moisture content and density. tangential, and longitudinal shrinkage were also determined by IS 6874 (2008). A total of 75 blocks were taken for this parameter.

\section{F. Statistical Analysis}

The statistical analyses like MANOVA followed by Tukey's test were performed to compare the differences in anatomical and physical characteristics between height positions using SPSS 16 software. 


\section{RESULT AND DISCUSSION}

The study reveals that culms of C. mannii were solid, unlike most of the other bamboo species. The anatomical characteristics given in Figure 2 showed that the outermost layer epidermis had radially elongated thick-walled cells with sunken stomata. The vascular bundles were scattered and arranged in 6-7 rows. The vascular bundles were incomplete, smaller in size, and thick fibrous sheath in the outer zone. The vascular bundles were well developed in the inner and middle zones. All the vascular bundles were examined as Type II (central vascular strand with larger sclerenchymatous sheath at the protoxylem than at metaxylem and phloem). The ground tissue was represented by thin-walled and rounded parenchyma cells having small intercellular spaces. The vascular bundles were also of a similar type along with the culm height. The vascular bundles in the middle zone are well developed and differentiated; therefore, the middle zone's vascular bundles are diagnostic features for identifying this species. The presence of Type II vascular bundles in this species corroborates the findings of Grosser and Liese (1971).

The number and size of vascular bundles are also characteristics of bamboo species (Latif \& Tamizi, 1992; Sharma et al., 2017). The number of vascular bundles increased from inner to outer zone radially at the bottom, middle and top positions (Figure 3). The maximum number of vascular bundles in the outer zone is due to their small size and compact arrangement. The present results agree with the findings of Razak et al. (2012); Maya, Narasimhamurthy, and Pandey (2013); Kumar, Sharma, and Sharma (2015) and Sharma et al. (2017). On the other hand, there was a decrease in the number of vascular bundles from bottom to top positions. The number of vascular bundles per $\mathrm{mm}^{2}$ at the bottom, middle and top positions were $10.12,9.86$, and 9.78. There was non-significant variation in the number of vascular bundles in vertical directions due to less difference in culm diameter from bottom to top.
The radial and tangential diameters ratio determines the size of vascular bundles in bamboos (Sharma et al., 2017). In C. mannii, radial diameter increased from inner to outer zone (radial). It decreased from bottom to top position (vertical), whereas tangential diameter decreased in radial and vertical directions (Figures 4 \& 5). The vascular bundle size (R/T ratio) in $C$. mannii increased radially and was uniform vertically (Figure 6). The increase in the $\mathrm{R} / \mathrm{T}$ ratio from the inner to the outer zone is due to more radial diameter of vascular bundles in the outer zone than inner and middle zones. Similar observations are reported in other bamboo species by Wang, Pu, Ding, Wan, and Lin (2011); Kumar et al. (2015) and Xing et al. (2015).

The metaxylem vessels were barrel-shaped with simple perforation and oval diameter. In the radial direction, vessel length and vessel diameter decreased significantly from the inner to the outer zone. In the vertical direction, vessel length decreased significantly from bottom to top, whereas vessel diameter increased from bottom to middle and decreased towards top positions (Table 2). The maximum diameter of metaxylem vessel in the middle zone of bottom and middle positions shows that metaxylem vessels are fully grown, and vascular bundles are well developed. The decrease in metaxylem vessel diameter in the top position may be due to a decrease in the size of vascular bundles along with the culm height. The present results agree with the findings of Londoño, Camayo, Riano, and Lopez (2002); Wang et al. (2011), Norul Hisham, Othman, Rokiah, Latif, Ani, and Tarmizi (2006); Xing, Qi, Xie, Hao, Qin, and Chen (2015) and Sharma et al. (2017).

The fibres are present in the form of isolated caps around the vascular bundles. They are elongated with pointed tips and provide mechanical support. The fibre characteristics, namely fibre length, fibre diameter, fibre lumen diameter, and fibre wall thickness, determine the raw material's suitability for pulp and paper making (Kaur \& Dutt, 2013; Sharma, Sharma, 

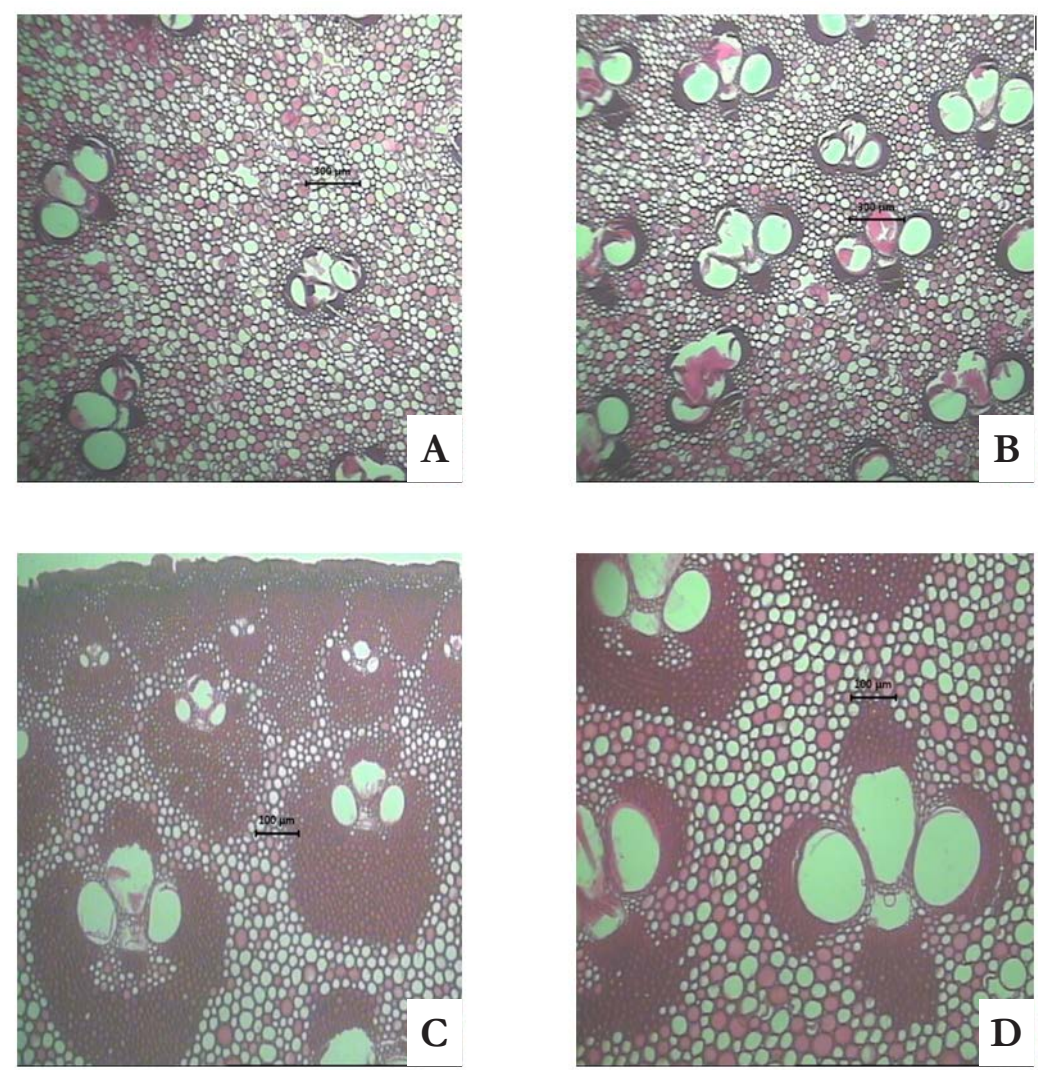

Figure 2 Cross-section of the culm of C. mannii: inner zone (A), middle zone (B), outer zone (C), and Type II vascular bundle (D)

Bage, Gogoi, and Pangging, 2018). The fibre length and fibre diameter increased from the inner to the middle zone and radially decreased in the outer zone. The significant variations in these parameters were observed in the bottom position only. Fibre lumen diameter non significantly decreased from inner to outer zone in the bottom position, but there was significant variation in top position. The fibre lumen diameter increased significantly from the inner to the middle zone and decreased in the outer zone. There was significant variation in fibre lumen diameter from bottom to top.

On the other hand, a significant increase in the fibre wall thickness was observed both in radial and vertical directions (Table 2). A perusal of literature reveals that fibre length varies from species to species in bamboos. They are $20-40 \%$ shorter in the inner part of the culm, and there is also a slight reduction in fibre length along with height. It is also associated with internode length (Liese, 1998). In this study, the fibres are shorter in the inner zone and confirm the findings of Liese (1998). The decrease in fibre length, fibre diameter and fibre lumen diameter from bottom to top are in agreement with Abdullah-Siam, Uyup, Husain, Mohmod, and Awalludin (2019). The radial and vertical increases in wall thickness are related to the compact arrangement of vascular bundles in the outer zone and reduced cell wall thickness in the top position. The present results confirm the findings of other workers (Xing et al., 2015; Kumar et al., 2015; Sharma et al., 2017).

The derived indices for suitability of any fibrous raw material depend on fibre length and its various dimensions. Runkel's ratio, flexibility coefficient, slenderness ratio, Luce's shape factor and rigidity coefficient are important indices to determine the physical properties of 


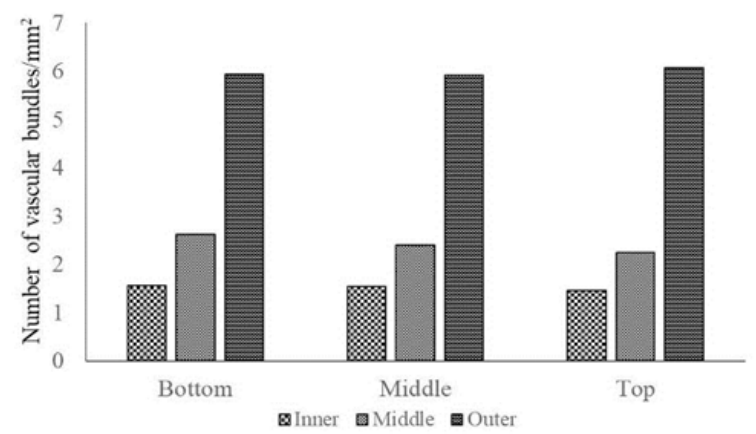

Figure 3

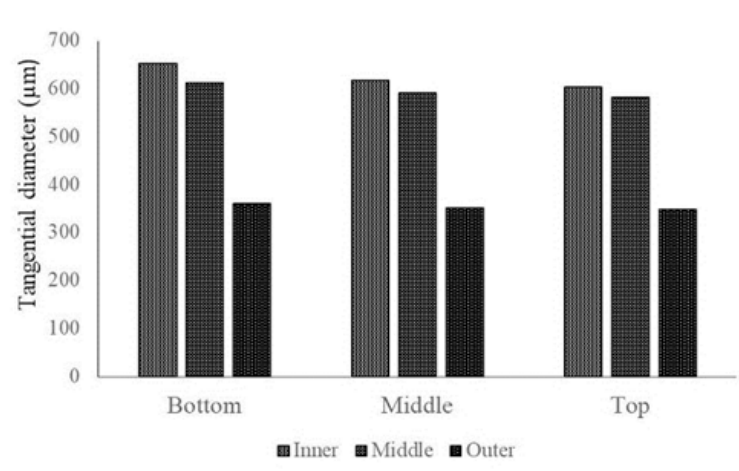

Figure 5

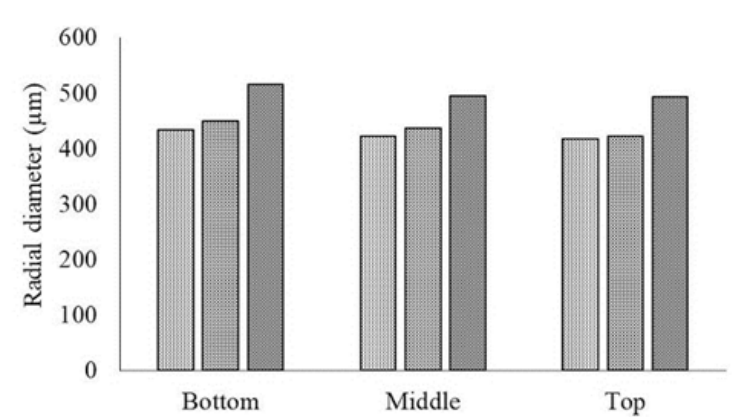

aInner aMiddle घOuter

Figure 4

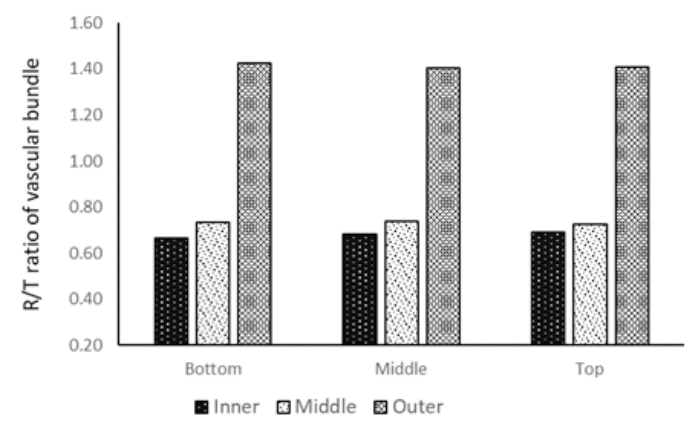

Figure 6

Figures 3-6: Histograms showing the number (Figure3), radial and tangential diameters (Figures 4 \&5) and $\mathrm{R} / \mathrm{T}$ ratio of vascular bundles of $C$. mannii (Figure 6)

pulp. The fibres with Runkel's ratio less than one are considered best for pulp and paper making (Sharma et al., 2018). The various derived indices presented in Table 3 showed that all derived indices of $C$. mannii varied non significantly both in radial and vertical direction and corroborates the findings of Latif and Tamizi (1992). Runkel's ratio of this species was more than one which shows that fibres were highly thick-walled. Similar observations are also reported in other bamboo species (Sharma, Dutt, Upadhyaya, \& Roy, 2011, Zhan, Zhao, Li, Wang, \& Wang, 2017). The flexibility coefficient determines the strength of the paper. The fibres with a flexibility coefficient of less than 30 are very rigid, and more than 75 are considered very elastic fibres (Bektas, Tutus, \& Eroglu, 1999). The flexibility coefficient in this species was less than 30 . Hence, the fibres are very rigid. The present results are contrary to the findings of Sadiku, Oluyege, \& Ajauji (2016). Therefore, the thick walled and rigid fibres condition did not fulfil its requirements as a superior fibrous material for pulp and paper. It may be used for making good quality handicrafts, basketry and furniture items based on the present study.

The slenderness ratio of fibres more than 70 is considered good for pulp and paper (Bektas et al., 1999). A high value of slenderness ratio is responsible for well bonded and better-formed paper (Ashori \& Nourbaksh, 2009). The 


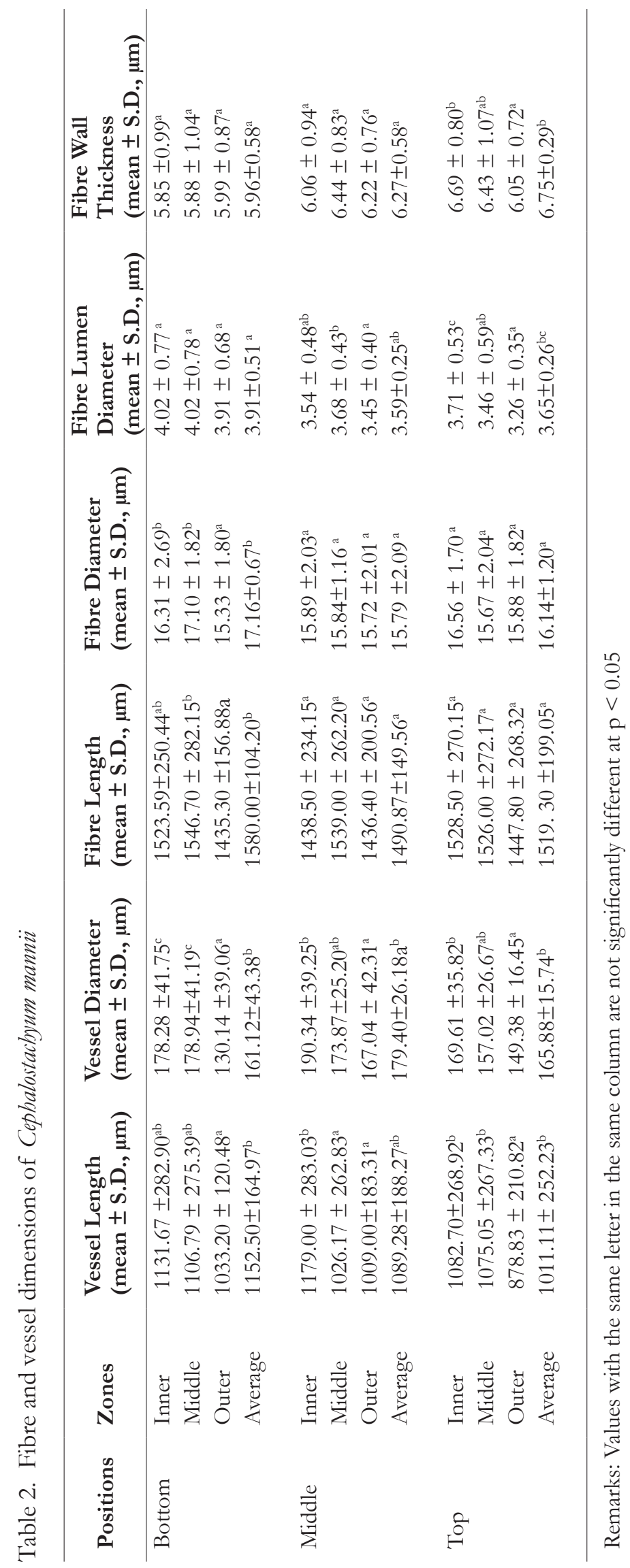


Table 3. Derived indices of Cephalostachyum mannii

\begin{tabular}{|c|c|c|c|c|c|c|}
\hline Positions & Zones & $\begin{array}{l}\text { Runkel's } \\
\text { Ratio }\end{array}$ & $\begin{array}{l}\text { Flexibility } \\
\text { Coefficient }\end{array}$ & $\begin{array}{c}\text { Slenderness } \\
\text { Ratio }\end{array}$ & $\begin{array}{c}\text { Luce's Shape } \\
\text { Factor }\end{array}$ & $\begin{array}{c}\text { Rigidity } \\
\text { Coefficient }\end{array}$ \\
\hline Bottom & $\begin{array}{l}\text { Inner } \\
\text { Middle } \\
\text { Outer } \\
\text { Average }\end{array}$ & $\begin{array}{c}3.08 \pm 0.63^{\mathrm{a}} \\
3.28 \pm 0.45^{\mathrm{a}} \\
3.17 \pm 0.41^{\mathrm{a}} \\
3.18 \pm 0.35^{\mathrm{a}}\end{array}$ & $\begin{array}{l}26.04 \pm 4.27^{\mathrm{a}} \\
24.39 \pm 2.56^{\mathrm{a}} \\
25.08 \pm 2.52^{\mathrm{a}} \\
25.17 \pm 2.47^{\mathrm{a}}\end{array}$ & $\begin{array}{r}100.78 \pm 16.48^{a} \\
100.93 \pm 13.87^{a} \\
95.41 \pm 13.02^{a} \\
99.04 \pm 9.02^{a}\end{array}$ & $\begin{array}{l}0.87 \pm 0.04^{a} \\
0.88 \pm 0.02^{a} \\
0.88 \pm 0.02^{a} \\
0.88 \pm 0.02^{a}\end{array}$ & $\begin{array}{l}0.74 \pm 0.04^{a} \\
0.76 \pm 0.03^{a} \\
0.75 \pm 0.03^{a} \\
0.75 \pm 0.02^{a}\end{array}$ \\
\hline Middle & $\begin{array}{l}\text { Inner } \\
\text { Middle } \\
\text { Outer } \\
\text { Average }\end{array}$ & $\begin{array}{l}3.50 \pm 0.51^{\mathrm{a}} \\
3.59 \pm 0.39^{\mathrm{a}} \\
3.45 \pm 0.36^{\mathrm{a}} \\
3.52 \pm 0.17^{\mathrm{a}}\end{array}$ & $\begin{array}{l}23.06 \pm 2.75^{\mathrm{a}} \\
22.64 \pm 2.15^{\mathrm{a}} \\
23.31 \pm 1.99^{\mathrm{a}} \\
23.00 \pm 0.95^{\mathrm{a}}\end{array}$ & $\begin{array}{r}101.86 \pm 15.73^{a} \\
88.79 \pm 7.83^{a} \\
92.76 \pm 8.81^{a} \\
94.47 \pm 9.96^{a}\end{array}$ & $\begin{array}{l}0.90 \pm 0.02^{\mathrm{a}} \\
0.90 \pm 0.02^{\mathrm{a}} \\
0.89 \pm 0.02^{\mathrm{a}} \\
0.89 \pm 0.01^{\mathrm{a}}\end{array}$ & $\begin{array}{l}0.77 \pm 0.03^{a} \\
0.77 \pm 0.02^{a} \\
0.77 \pm 0.02^{a} \\
0.77 \pm 0.01^{a}\end{array}$ \\
\hline Top & $\begin{array}{l}\text { Inner } \\
\text { Middle } \\
\text { Outer } \\
\text { Average }\end{array}$ & $\begin{array}{l}3.70 \pm 0.38^{\mathrm{a}} \\
3.76 \pm 0.26^{\mathrm{a}} \\
3.79 \pm 0.30^{\mathrm{a}} \\
3.75 \pm 0.21^{\mathrm{a}}\end{array}$ & $\begin{array}{l}21.99 \pm 1.82^{\mathrm{a}} \\
21.77 \pm 1.27^{\mathrm{a}} \\
21.53 \pm 1.35^{\mathrm{a}} \\
21.76 \pm 1.02^{\mathrm{a}}\end{array}$ & $\begin{array}{r}92.79 \pm 8.81^{\mathrm{a}} \\
94.59 \pm 9.43^{\mathrm{a}} \\
96.25 \pm 15.17^{\mathrm{a}} \\
94.55 \pm 6.94^{\mathrm{a}}\end{array}$ & $\begin{array}{l}0.91 \pm 0.01^{\mathrm{a}} \\
0.91 \pm 0.01^{\mathrm{a}} \\
0.91 \pm 0.01^{\mathrm{a}} \\
0.91 \pm 0.01^{\mathrm{a}}\end{array}$ & $\begin{array}{l}0.78 \pm 0.02^{a} \\
0.78 \pm 0.01^{a} \\
0.79 \pm 0.01^{a} \\
0.78 \pm 0.01^{a}\end{array}$ \\
\hline
\end{tabular}

Remarks: Values with the same letter in the same column are not significantly different at $\mathrm{p}<0.05$

low value of Luce's shape factor and rigidity coefficient is related to better tensile, tearing, bursting strength and also folding resistance of paper (Kaur \& Dutt, 2013; Sharma et al., 2011, 2018). In C. mannii, the slenderness ratio was more than 70 , but Luce's shape factor and rigidity coefficient were higher than other bamboo species (Sharma et al., 2011; Abdullah Siam et al., 2019).

Density, moisture content and shrinkage are important physical properties. They affect the dimensional stability and strength of bamboos (Anokye et al., 2014). These properties are also related to anatomical characteristics and determine the suitability of bamboos for various uses. The results are given in Table 4 show an increase in density from inner to outer zone in the radial direction and from bottom to top in the vertical direction. On the other hand, moisture content decreased from the inner to outer zone in the radial direction. It increased from bottom to middle and then decreased towards the top. Both density and moisture content varied significantly in the radial direction but non-significantly in the vertical direction. More compactly arranged vascular bundles with a high percentage of fibres and less parenchyma may increase density and decrease moisture content in both vertical and radial directions. The maximum moisture content in the middle position may be due to well-developed vascular bundles having a maximum diameter in the inner and middle zones. The present study corroborates the findings of other works (Yu, Jiang, Hse, \& Shupe, 2008; Nordahlia, Anwar, Hamdan, Zaidon, Paridah, \& Rajak, 2012; Anokye et al., 2014; Sharma et al., 2017; 2019) who reported similar results in other bamboo species.

Longitudinal shrinkage was minimal like in other bamboo species. Radial shrinkage was higher than tangential shrinkage. Both radial and tangential shrinkage decreased from bottom to top with significant variation between the bottom and middle positions (Table 5). In general, the rays are absent in bamboos like other monocotyledons which may be the probable reason for higher radial shrinkage and confirms the findings of Anokye et al. (2014). The shrinkage properties in the bamboos are also related to the anatomical structure. The alignment of microfibrils concerning the longitudinal axis in the S2 layer of fibres is responsible for this property in 
Table 4. Density and moisture content of Cephalostachyum mannii

\begin{tabular}{clcc}
\hline \multicolumn{1}{c}{ Position } & \multicolumn{1}{c}{ Zone } & Density (g/cc) & Moisture content (\%) \\
\hline Bottom & Inner & $0.37 \pm 0.03^{\mathrm{a}}$ & $191.95 \pm 21.19^{\mathrm{c}}$ \\
& Middle & $0.43 \pm 0.05^{\mathrm{b}}$ & $158.73 \pm 22.81^{\mathrm{b}}$ \\
& Outer & $0.63 \pm 0.06^{\mathrm{c}}$ & $90.13 \pm 12.59^{\mathrm{a}}$ \\
\multirow{3}{*}{ Middle } & Average & $0.48 \pm 0.12^{\mathrm{b}}$ & $146.22 \pm 47.16_{\mathrm{b}}$ \\
& Inner & $0.35 \pm 0.05^{\mathrm{a}}$ & $216.05 \pm 44.97^{\mathrm{c}}$ \\
& Middle & $0.42 \pm 0.04^{\mathrm{b}}$ & $168.20 \pm 19.65^{\mathrm{b}}$ \\
& Outer & $0.64 \pm 0.05^{\mathrm{c}}$ & $85.70 \pm 11.42^{\mathrm{a}}$ \\
Top & Average & $0.47 \pm 0.14^{\mathrm{b}}$ & $156.65 \pm 61.42^{\mathrm{b}}$ \\
& Inner & $0.39 \pm 0.05^{\mathrm{a}}$ & $194.11 \pm 37.35^{\mathrm{c}}$ \\
& Middle & $0.46 \pm 0.05^{\mathrm{b}}$ & $151.32 \pm 25.47^{\mathrm{b}}$ \\
& Outer & $0.71 \pm .0 .07^{\mathrm{c}}$ & $73.67 \pm 13.45^{\mathrm{a}}$ \\
& Average & $0.52 \pm 0.02^{\mathrm{b}}$ & $139.54 \pm 57.20^{\mathrm{b}}$ \\
\hline
\end{tabular}

Remarks: Values with the same letter in the same column are not significantly different at $\mathrm{p}<0.05$

Table 5. Shrinkage in culms of Cephalostachyum mannii

\begin{tabular}{cccc}
\hline Position & Radial Shrinkage & Tangential Shrinkage & Longitudinal Shrinkage \\
\hline Bottom & $10.83 \pm 1.73^{\mathrm{b}}$ & $8.82 \pm 2.77^{\mathrm{b}}$ & $0.25 \pm 0.32^{\mathrm{a}}$ \\
Middle & $8.45 \pm 1.09^{\mathrm{a}}$ & $6.16 \pm 2.33^{\mathrm{a}}$ & $0.31 \pm 0.60^{\mathrm{a}}$ \\
Top & $7.74 \pm 1.10^{\mathrm{a}}$ & $5.17 \pm 2.01^{\mathrm{a}}$ & $0.24 \pm 0.29^{\mathrm{a}}$ \\
\hline
\end{tabular}

Remarks: Values with the same letter in the same column are not significantly different at $\mathrm{p}<0.05$

wood. The bamboo fibres are polylamellate in nature and have narrow lamellae with a large microfibril angle of $85-90^{\circ}$ and broad lamellae with angle parallel to the longitudinal axis fibres (Parameswaran \& Liese, 1976). The maximum shrinkage (both radial and tangential) at the bottom may be due to the presence of highly lignified fibres in the outer zone.

\section{CONCLUSION}

The anatomical characteristics revealed that Type II vascular bundles are present in the culms of Cephalostachyum mannii. The vascular bundles were well-developed in the middle zone. Hence, the middle zone of both bottom and middle positions can be used to identify this species. Most of the anatomical characteristics varied significantly in both radial and vertical directions. In terms of fibre morphology, the fibres were long, rigid and highly thick-walled.
The slenderness ratio was desirable, but other indices did not fulfil its requirement as a superior material for pulp and paper. Among physical properties, density increased both in radial and vertical directions, whereas moisture content decreased in these directions. Radial shrinkage was more than tangential shrinkage. Both radial and tangential shrinkage decreased from bottom to top. The fibres of $C$. manii were thick-walled and rigid. Therefore, it did not fulfil the requirements as a superior fibrous material for pulp and paper. It may be used for making good quality handicrafts, basketry and furniture items based on the present study. However, the detailed study on its mechanical properties, the ultrastructure of fibre wall and its effect on physicomechanical properties need to be investigated for commercial purposes. 


\section{ACKNOWLEDGEMENT}

The authors are thankful to Director, North Eastern Regional Institute of Science and Technology, Nirjuli, to provide laboratory facilities.

\section{REFERENCES}

Abdullah-Siam, N., Uyup, M.K.A., Husain, H., Mohmod, A.L., \& Awalludin, M.F. (2019). Anatomical, physical, and mechanical properties of thirteen Malaysian bamboo species. BioResources, 14(2), 3925-3943.

Anokye, R., Kalong, R.M., Bakar, E.S., Ratnasingam, J., Jawaid, M., \& Awang, K. (2014). Variations in moisture content affect the shrinkage of Gigantochloa scortechinii and Bambusa vulgaris at different heights of the bamboo culm. BioResources, 9(4), 7484-7493.

Ashori, A., \& Nourbakhsh, A. (2009). Studies on Iranian cultivated paulownia- A potential source of fibrous raw material for paper industry. European Journal of Wood and Wood Products, 67, 323-327.

Bektas, I., Tutus, A., \& Eroglu, H. (1999). A study of the suitability of calabrian pine (Pinus brutia Jen.) for pulp and paper manufacture. Turkish Journal of Agriculture and Forestry, 23(3), 589597.

Cao, S., Ma, X., Lin, L., Huang, F., Huang, L. \& Chen, L. (2014). Morphological and chemical characterization of green bamboo (Dendrocalamopsis oldhami (Munro) Keng F.) for dissolving pulp production. Bioresources, 9(3), 4528-4539.

Dutt, D., Upadhyaya, J.S., Tyagi, C.H. \& Malik, R.S. (2004). Studies on pulp and paper making characteristics of some Indian non-woody fibrous raw materials: Part II. Journal of Scientific and Industrial research 63, 58-67.

FSI (2019). Indian state of forest report. Retrieved from http:/www.fsi.nic.in. on the $1^{\text {st }}$ October 2020.

Grosser, D., \& Liese, W. (1971). On the anatomy of Asian bamboos with special reference to their vascular bundles. Wood Science and Technology, 5 , 290-312.

IS 6874 (2008). Methods of test for bamboos. Bureau of Indian Standards, New Delhi.

Johansen, D.A. (1940). Plant microtechnique. New
York: Mc Graw Hill Book Company.

Kaur, H., \& Dutt, D. (2013). Anatomical, morphological and chemical characterization of lignocellulosic bye products of lemon and sofia grasses obtained after recuperation of essential oils by steam distillation. Cellulose Chemistry Technology, 47(1-2), 83-94.

Kelemwork, S. (2009). Effects of some anatomical characteristics of Ethiopian lowland bamboo (Oxytenanthera abyssinica) on physical and mechanical properties. Journal of Bamboo and Rattan, 8, 161-174.

Kumar, Y.B., Sharma, M., \& Sharma, C.L. (2015). Anatomical and physical properties of Bambusa mizorammeana Naithani. International Journal of Advanced Research, 3(4), 479-486.

Kharlyngdoh, E., \& Barik, S. (2008). Diversity, distribution pattern and use of bamboos in Meghalaya. Journal of Bamboo and Rattan, 7(1 \&2), 73-90.

Latif, A.M., \& Tamizi, M.M. (1992). Variation in anatomical properties of three Malaysian Bamboos from natural stand. Journal of Tropical Forest Science, 5(1), 90-96.

Liese, W. (1998). The anatomy of bamboo culms. Tecbnical Report 18. INBAR, Beijing.

Londoño, X., Camayo, G.C., Riaño, N.M., \& López, Y. (2002) Characterization of the anatomy of Guadua angustifolia (Poaceae: Bambusoideae) culms. Bamboo Science and Culture, 16(1), 18-31.

Luce, G. E. (1970). The physics and chemistry of wood pulp fibres. Tappi 8, 278.

Maya, C., Narasimhamurthy, \& Pandey, C. N. (2013) A study on anatomical and physical properties of cultivated bamboo (Oxytenanthera monostigama). International Journal Current Science, 5, 62-66

Nordahlia, A.S., Anwar, U.M.K., Hamdan, H., Zaidon, A., Paridah, M.T., \& Rajak, A. (2012). Effects of age and height on selected properties of Malaysian bamboo (Gigantochloa levis). Journal of Tropical Forest Science, 24(1),102109.

Norul-Hisham, H., Othman, S., Rokiah, H., Latif, M.A., Ani, S., \& Tamizi, M.M. (2006). Characterization of bamboo Gigantochloa scortechinic at different ages. Journal of Tropical Forest Science, 18(4), 236-242.

Parameswaran, N., \& Liese, W. (1976). On the fine structure of bamboo fibres. Wood Science and Technololgy, 10, 231-246. 
Razak, W., Mohamed, A., Samsi, H.W., Yunus, A.A.M., \& Moktar, J. (2006). Physical characteristics, anatomy and properties of managed Gigantochloa scortechinii natural bamboo stands. Journal of Plant Sciences, 1(2), 144-153.

Razak, W. Mustafa, M.T., Sulaiman, O., Mohamed, A., Hassan, A., \& Khalid, I. (2010). Anatomical and physical properties of cultivated two and four year old Bambusa vulgaris. Sains Malaysiana, 39(4), 571-579.

Razak, W., Mustafa, M.T., Rahman, S., Salam, M.A., Sulaiman, O., Sudin, M., \& Rasat, M.S.M. (2012). Relationship between physical, anatomical and strength properties of 3 year old cultivated tropical bamboo Gigantochloa scortecbinii. Journal of Agricultural and Biological Science, 7(10), 782-791.

Runkel, R.O.H. (1949). Uber die herstellung von zellstoff aus holz der gattung eucalyptus und versuche mit zwei unterchiedlichen eucalyptussarten. Das Papier, 3, 476-490.

Sadiku, N.A., Oluyege, A.O., \& Ajauji, B. (2016). Fibre dimension and chemical characterization of naturally grown Bambusa vulgaris for pulp and paper production. Journal of Bamboo and Rattan, 15(1-4), 33-43.

Sharma, A.K., Dutt, D., Upadhyaya, J.S., \& Roy, T.K. (2011). Anatomical, morphological, and chemical characterization of Bambusa tulda, Dendrocalamus hamiltonii, Bambusa balcooa, Malocana baccifera, Bambusa arundinacea and Eucalyptus tereticornis. BioResources, 6(4), 50625073.

Sharma, M., Sharma, C.L., Tado, N. \& Laishram, D. (2019). Physical properties of apatani bamboo (Phyllostachys bambusoides Siebold \& Zucc.) in relation to age and height. International Journal of Advances in Science Engineering and Technology, 7(3), 76-78,

Sharma, M., Sharma, C.L., \& Laishram, D. (2017). Variation in anatomical and physical properties of some Schizostachyum species of Manipur, India. Journal of Indian Academy of Wood Science, 14(1), 79-90.
Sharma, M., Sharma, C.L., Bage, M., Gagoi, B.R., \& Pangging, G. (2018). Anatomical characteristics and fibre dimensions of some grass species of arunachal pradesh and their potential for pulp and paper. Journal of Bioresources, 5(1), 41-48.

Stapleton, C.M.A., Li, D.Z. \& Xue, J.R. (1997). A new combination in Cephalostachyum with notes on names in Neomicrocalamus (Gramineae: Bambusoideae). Kew Bulletin, 52(3), 699-702.

Tan, T., Rahbar, N., Allameh, S.M., Kwofie, S., Dissmore, D., Ghavami, K., \& Soboyejo, W.O. (2011). Mechanical properties of functionally graded hierarchical bamboo structures. Acta Biomaterialica, 7(10), 3796-3803.

Varghese, M., Subramanian, V.K.N., Bennet, S.S.R. \& Jagadees, S. (1995). Genetic effects on wood and fibre traits of Eucalyptus grandis provenances. In eucalyptus plantation: Improving fibre yield and quality. CRCTHFIUFRO Conference, pp 64- 67.

Wang, S.G., Pu, X.L., Ding, Y.L., Wan, X.C. \& Lin, S.Y. (2011). Anatomical and chemical properties of Fargesia yunnanensis. Journal of Tropical Forest Science, 23(1), 73-81.

Wangaard, F.F. (1962). Contribution of hardwood to the properties of kraft wood pulp. Tappi 45 , 548-556.

Xing, H.Y., Qi, J.Q., Xie, J.L., Hao, J.F., Qin, B.D., \& Chen, S.M. (2015). Variation in anatomical characteristics of bamboo. Bambusa rigida. Sains Malaysiana, 44(1), 17-23.

Yu, H.Q., Jiang, Z.H., Hse, C.Y. \& Shupe, T.F. (2008). Selected physical and mechanical properties of Moso bamboo (Phyllostachys pubescens). Journal of Tropical Science, 20(4), 258-263.

Zhan, H., Zhao, J., Li, M., Wang, C. \& Wang, S. (2017). Anatomical and chemical properties of bamboo sheaths (Dendrocalamus brandisiz) as potential raw material for paper making. European Journal of Wood and Wood Products, 75(5), 847-851. 